\title{
Treatment of influenza virus-related critical illness during continuous renal replacement therapy: take caution with dosing
}

\author{
Patrick M. Honore*, Luc Kugener, Sebastien Redant, Rachid Attou, Andrea Gallerani and David De Bels
}

In their discussion, Chow et al. state that for patients who cannot tolerate or absorb enteric oseltamivir due to gastric stasis, malabsorption, or other gastrointestinal processes, intravenous peramivir may be an alternative [1]. They advise a single dose of $600 \mathrm{mg}$ via intravenous infusion, given over $15-30 \mathrm{~min}$ [1]. The question that arises is the following: what is the dose to be given during continuous renal replacement therapy (CRRT)? According to the manufacturer's recommendations, the dose should be adjusted in line with the degree of reduction in creatinine clearance [2]. In a recent case report by Dillon et al., a dose of $200 \mathrm{mg}$ daily, the recommended dose for patients with creatinine clearance of $30-49 \mathrm{~mL} / \mathrm{min}$, was given to a patient with acute kidney injury (AKI) managed with CRRT [2]. In practice, as the plasma protein unbound fraction approaches 1 (as is the case with peramivir) and the molecular weight of the drug is low (below 20,000 Da), the sieving coefficient can be estimated to be 1 [3]. As a consequence, in this case report, the dosage scheme ( $200 \mathrm{mg}$ daily) achieved a smaller serum peak concentration, larger volume of distribution, and a shorter half-life, illustrating the significant differences in pharmacokinetic (PK)/ pharmacodynamic (PD) target attainment when drugs are administered in the setting of continuous venovenous hemodiafiltration (CVVHDF) [2]. Scheetz et al. recommend a steady-state concentration of $17,078 \mathrm{ng} /$ $\mathrm{mL}$, which was averaged from peak and trough concentrations in adult patients with normal renal function [4]. Based on this recommendation, the patient reported by

This comment refers to the article available at https://doi.org/10.1186/ s13054-019-2491-9.

* Correspondence: Patrick.Honore@CHU-Brugmann.be

ICU Department, Centre Hospitalier Universitaire Brugmann-Brugmann

University Hospital, Place Van Gehuchtenplein, 4, 1020 Brussels, Belgium
Dillon et al. would have required more than $800 \mathrm{mg}$ given the CRRT settings [2, 4]. Doses of peramivir during CRRT vary from 200 to $800 \mathrm{mg}$ per day in various case reports. This huge difference in dose will have a dramatic influence upon PK/PD during CRRT. Peramivir does not seem to possess any of the classic indications for therapeutic drug monitoring (TDM) (i.e., narrow therapeutic index, high interpatient variability, high intrapatient variability) in patients with normal organ function [5]. However, in patients with critical illness requiring extracorporeal therapies, TDM may provide useful information regarding pharmacokinetic variations and pharmacodynamic target attainment in order to avoid severe underdosing and treatment failure [5].

\begin{abstract}
Abbreviations
AKI: Acute kidney injury; CRRT: Continuous renal replacement therapy; CWHDF: Continuous veno-venous hemodiafiltration; PD: Pharmacodynamic; PK: Pharmacokinetic; TDM: Therapeutic drug monitoring
\end{abstract}

\section{Acknowledgements}

None.

\section{Authors' contributions}

$\mathrm{PMH}, \mathrm{SR}$, and DDB designed the paper. All authors participated in drafting and reviewing. The authors read and approved the final version of the manuscript.

\section{Funding}

None

\section{Availability of data and materials Not applicable.}

Ethics approval and consent to participate Not applicable.

\section{Consent for publication}

Not applicable.

\section{Competing interests}

The authors declare that they have no competing interests. 
Received: 11 February 2020 Accepted: 26 February 2020

Published online: 03 March 2020

\section{References}

1. Chow EJ, Doyle JD, Uyeki TM. Influenza virus-related critical illness: prevention, diagnosis, treatment. Crit Care. 2019;23:214

2. Dillon RC, Witcher R, Cies JJ, Moore WS 2nd, Chopra A. Pharmacokinetics of peramivir in an adolescent patient receiving continuous venovenous hemodiafiltration. J Pediatr Pharmacol Ther. 2017;22(1):60-4. https://doi.org/ 10.5863/1551-6776-22.1.60.

3. Bohler J, Donauer J, Keller F. Pharmacokinetic principles during continuous renal replacement therapy: drugs and dosage. Kidney Int Suppl. 1999;72: S24-8.

4. Scheetz MH, Griffith MM, Ghossein C, et al. Pharmacokinetic assessment of peramivir in a hospitalized adult undergoing continuous veno-venous hemofiltration. Ann Pharmacother. 2011;45(12):e64.

5. Winter ME. Basic clinical pharmacokinetics. 4th ed. Philadelphia: Lippincott Williams \& Wilkins; 2004. p. 61-7.

\section{Publisher's Note}

Springer Nature remains neutral with regard to jurisdictional claims in published maps and institutional affiliations. 